\title{
PENGARUH PENGELOLAAN MODAL KERJA TERHADAP TINGKAT PROFITABILITAS (ROA) PADA PERUSAHAAN MAKANAN DAN MINUMAN YANG TERDAFTAR DI BEI PERIODE TAHUN 2013-2017
}

\author{
${ }^{1)}$ Zeze Zakaria Hamzah, ${ }^{2)}$ Dian Ayu Anggitya Rahma \\ ${ }^{1)}$ Dosen Program Studi Manajemen, STIE Dewantara \\ J1. Raya Pemda Bojong Depok Baru III, Karadenan, Cibinong, Bogor, Jawa Barat 16913,Indonesia \\ Email: zeze.zakaria@dewantara.ac.id \\ ${ }^{2)}$ Alumni Program Studi Manajemen, STIE Dewantara \\ Jl. Raya Pemda Bojong Depok Baru III, Karadenan, Cibinong, Bogor, Jawa Barat 16913,Indonesia \\ Email: rahmaanggitya@gmail.com
}

\begin{abstract}
The purpose of this research is capital investment in food and beverage companies listed on the Indonesia Stock Exchange in the period 2013-2017. The type of data used in research is quantitative causality. Data samples were taken using purposive sampling method. The results of this study indicate that working capital variables consisting of current ratio, accounts receivable turnover, preparation turnover and simultaneous working capital turnover (together) are significantly related to profitability (ROA). With a partial ratio (ROA) with a sig value of $0.045<0.05$ and $a$ value of $t$ arithmetic 2.097> 2.042 and accounts receivable turnover (ROA) with a sig value of $0.013<0.05$ and a $t$ value of 2.634> 2.042. Inventory turnover and working capital do not affect profitability (ROA). Then from the results of the Beta Standard Coefficient shows the most dominant variable is the current ratio with a value of 0.468. From the regression results in this study the influence of the independent variables amounted to $32.7 \%$ while the remaining $67.3 \%$ was needed by other factors outside this study.
\end{abstract}

Keywords: Current Ratio, Receivables Turnover, Inventory Turnover, Working Capital Turnover, Profitabibility (ROA).

\begin{abstract}
ABSTRAK
Tujuan dari penelitian ini adalah untuk menguji pengaruh pengelolaan modal kerja terhadap tingkat profitabilitas pada perusahaan makanan dan minuman yang terdaftar di BEI periode tahun 2013-2017. Jenis data yang digunakan dalam penelitian adalah kuantitatif kausalitas. Sampel data diambil menggunakan metode purposive sampling. Hasil penelitian ini menunjukan bahwa variabel modal kerja yang terdiri dari rasio lancar, perputaran piutang, perputaran persediaan dan perputaran modal kerja secara simultan (bersama-sama) berpengaruh secara signifikan terhadap tingkat profitabilitas (ROA). Secara parsial rasio lancar berpengaruh terhadap (ROA) dengan nilai sig sebesar $0.045<0,05$ dan nilai t hitung 2,097 > 2,042 dan perputaran piutang berpengaruh terhadap (ROA) dengan nilai sig sebesar $0.013<0,05$ dan nilai t hitung 2,634> 2,042. Perputaran persedian dan perputaran modal kerja tidak berpengaruh terhadap profitabilitas (ROA). Kemudian dari hasil Standardized Coefficients Beta menunjukan bahwa variabel paling dominan adalah rasio lancar dengan nilai sebesar 0,468. Dari hasil regresi dalam penelitian ini pengaruh dari keempat variabel bebas adalah sebesar 32,7\% sedangkan sisanya $67,3 \%$ dipengaruhi oleh faktor lain diluar penelitian ini.
\end{abstract}

Kata kunci: Rasio Lancar, Peputaran Piutang, Perputaran Persediaan, Perputaran Modal Kerja, Profitabilitas (ROA).

\section{PENDAHULUAN}

\subsection{Latar Belakang}

Industri makanan dan minuman menjadi salah satu sektor manufaktur andalan dalam memberikan kontribusi terhadap pertumbuhan ekonomi nasional. Industri makanan dan minuman memiliki tingkat penjualan yang lebih besar dibandingkan dengan industri-industri lain. 
Tingkat penjualan ini yang memiliki pengaruh yang sangat penting terhadap laba yang diperoleh perusahaan. Dalam aktivitasnya, perusahaan selalu memerlukan dana, baik untuk membiayai kegiatan operasional sehari-hari maupun investasi jangka panjang. Dana yang digunakan disebut modal kerja.

Modal kerja merupakan salah satu faktor terpenting yang dapat mempengaruhi kelangsungan kegiatan operasional perusahaan.Ukuran kinerja yang sering digunakan pada suatu perusahaan adalah profitabilitas. Profitabilitas menunjukan kemampuan perusahaan mengelola penggunaan aktiva dalam memperoleh laba atau hasil akhir operasional perusahaan selama satu periode. Profitabilitas perusahaan dapat dipengaruhi oleh rasio lancar, perputaran piutang, perputaran persediaan dan perputaran modal kerja dari masing-masing perusahaan.

Dari sektor industri barang konsumsi subsektor makanan dan minuman merupakan sektor yang paling mendominasi dan menyumbang emiten terbanyak pada sektor manufaktur. Ini menjadikan industri makanan dan minuman sering menjadi tumpuan dan memberi kontribusi terbesar dalam pertumbuhan sektor industri manufaktur Indonesia.

Tabel 1. Rata-rata ROA, Rasio Lancar, Perputaran Piutang, Perputaran Persediaan, Perputaran Modal Kerja Tahun 2013 sampai dengan 2017

\begin{tabular}{|l|c|c|c|c|c|}
\hline \multirow{2}{*}{\multicolumn{1}{|c|}{ Variabel }} & \multicolumn{5}{|c|}{ Tahun } \\
\cline { 2 - 6 } & $\mathbf{2 0 1 3}$ & $\mathbf{2 0 1 4}$ & $\mathbf{2 0 1 5}$ & $\mathbf{2 0 1 6}$ & $\mathbf{2 0 1 7}$ \\
\hline ROA & $10 \%$ & $8 \%$ & $8 \%$ & $8 \%$ & $4 \%$ \\
\hline Rasio Lancar & $1,71 \mathrm{x}$ & $1,83 \mathrm{x}$ & $1,78 \mathrm{x}$ & $2,06 \mathrm{x}$ & $1,96 \mathrm{x}$ \\
\hline $\begin{array}{l}\text { Perputaran } \\
\text { Piutang }\end{array}$ & $7,25 \mathrm{x}$ & $7,99 \mathrm{x}$ & $7,81 \mathrm{x}$ & $6,82 \mathrm{x}$ & $6,49 \mathrm{x}$ \\
\hline $\begin{array}{l}\text { Perputaran } \\
\text { Persediaan }\end{array}$ & $12,66 \mathrm{x}$ & $13,51 \mathrm{x}$ & $14,70 \mathrm{x}$ & $13,94 \mathrm{x}$ & $14,09 \mathrm{x}$ \\
\hline $\begin{array}{l}\text { Perputaran Modal } \\
\text { Kerja }\end{array}$ & $12,48 \mathrm{x}$ & $7,04 \mathrm{x}$ & $9,18 \mathrm{x}$ & $8,24 \mathrm{x}$ & $6,24 \mathrm{x}$ \\
\hline
\end{tabular}

Sumber: data diolah 2019

Berdasarkan tabel 1. dapat kita lihat bahwa ROA pada perusahaan makanan dan minuman dari tahun 2013-2017 mengalami fluktuasi bisa dilihat pada tahun rata-rata ROA pada tahun 2013 sebesar 10\%. Kemudian di tahun 2014-2016 mengalami penurunan sebesar 8\% dan pada tahun 2017 mengalami penurunan kembali mencapai angka 4\%. Perubahan ROA ini diperkirakan karena beberapa faktor, diantaranya rasio lancar, perputaran piutang, perputaran persediaan, dan perputaran modal kerja.

\subsection{Rumusan Masalah}

1. Bagaimana pengaruh Rasio Lancar (Current Ratio) terhadap Tingkat Profitabilitas (ROA)?

2. Bagaimana pengaruh Perputaran Piutang (Receivable Turnover) terhadap Tingkat Profitabilitas (ROA)?

3. Bagaimana pengaruh Perputaran Persediaan (Inventory Turnover) terhadap Tingkat Profitabilitas (ROA)?

4. Bagaimana pengaruh Perputaran Modal Kerja (Working Capital Turnover) terhadap Tingkat Profitabilitas (ROA)?

5. Bagaimana pengaruh variabel bebas (Rasio Lancar (Current Ratio), Perputaran Piutang (Receivable Turnover), Perputaran Persediaan (Inventory Turnover), Perputaran Modal Kerja (Working Capital Turnover)) secara simultan terhadap variabel terikat (ROA) ?

6. Variabel mana yang memiliki pengaruh paling dominan terhadap Tingkat Profitabilitas (ROA) ?

7. Bagaimana variabel pengelolaan modal kerja menjelaskan pengaruh terhadap tingkat profitabilitas (ROA) pada perusahaan?

\subsection{Tujuan Penelitian}

1. Untuk mengetahui bagaimana pengaruh Rasio Lancar (Current Ratio) terhadap Tingkat Profitabilitas (ROA). 
2. Untuk mengetahui bagaimana Perputaran Piutang (Receivable Turnover) terhadap Tingkat Profitabilitas (ROA).

3. Untuk mengetahui bagaimana Perputaran Persediaan (Inventory Turnover) terhadap Tingkat Profitabilitas (ROA).

4. Untuk mengetahui bagaimana Perputaran Modal Kerja (Working Capital Turnover) terhadap Tingkat Profitabilitas (ROA).

5. Bagaimana pengaruh variabel bebas (Rasio Lancar (Current Ratio), Perputaran Piutang (Receivable Turnover), Perputaran Persediaan (Inventory Turnover), Perputaran Modal Kerja (Working Capital Turnover)) secara simultan terhadap variabel terikat (ROA)

6. Untuk mengetahui variabel Rasio Lancar (Current Ratio), Perputaran Piutang (Receivable Turnover), Perputaran Persediaan (Inventory Turnover), Perputaran Modal Kerja (Working Capital Turnover) mana yang memiliki pengaruh paling dominan terhadap Tingkat Profitabilitas (ROA).

7. Untuk mengetahui Bagaimana variabel pengelolaan modal kerja menjelaskan pengaruh terhadap tingkat profitabilitas (ROA) pada perusahaan.

\section{TINJAUAN PUSTAKA}

\subsection{Pengertian Modal Kerja}

Modal kerja merupakan investasi perusahaan dalam bentuk uang tunai, surat berharga, piutang dan persediaan dan dikurangi dengan kewajiban lancar yang digunakan untuk membiayai aktiva lancar. (Sujarweni, 2017:186). Menurut (Fahmi, 2012:100) definisi modal kerja investasi sebuah perusahaan pada aktiva-aktiva jagka pendek seperti kas, sekuritas, persediaan dan piutang. Pengertian modal kerja merupakan modal yang digunakan untuk melakukan kegiatan operasional perusahaan (Kasmir, 2015:250).

\subsection{Rasio-rasio Modal Kerja}

Rasio modal kerja yaitu rasio yang digunakan untuk menganalisa dan mengiterpretasikan posisi keuangan jangka pendek (Munawir, 2014:71). Menurut (Munawir, 2014:72) untuk menilai posisi keuangan berikut ini yang dapat digunakan sebagai alat ukur sebagai berikut:

\section{Current Ratio/Rasio Lancar}

Perbandingan antara jumlah aktiva lancar dengan hutang lancar. (Munawi, 201:72). Rasio lancar juga dapat dikatakan sebagai bentuk untuk mengukur tingkat keamanan (Margin of Safety) suatu perusahaan. Perhituangan rasio lancar dilakukan dengan cara membandingkan antara total aktiva lancar dengan total hutang lancar (Kasmir, 2015:134). Rumus yang digunakan sebagai berikut :

Current ratio $=\frac{\text { aktiva lancar }}{\text { utang lancar }}$

\section{Acid Test Ratio atau Quick Ratio}

Perbandingan antara (aktiva lancarpersediaan) dengan hutang lancar. Rasio ini merupakan ukuran kemampuan perusahaan dalam memenuhi kewajiban-kewajibannya dengan tidak memperhitungkan persediaan, karena persediaan memerlukan waktu yang relatip lama untuk direalisir menjadi uang kas (Munawri, 2014:73). Untuk mencari Quick Ratio, diukur dari total aktiva lancar kemudian dikurangi dengan nilai sediaan, berikut rumus yang digunakan:

\section{Quick Ratio $=\frac{\text { Aset Lancar }- \text { Persediaan }}{\text { Utang Lancar }}$}

3. Receivable Turnover atau Perputaran Piutang

Inventory Turn Over atau merupakan rasio yang menunjukan berapa kali persediaan dapat berputar dalam satu tahun. Semakin tinggi tingkat persediaan, maka 
semakin cepat dana yang tertanam dalam persediaan berputar kembali menjadi uang kas. (A. Sugiono dan Edi Untung, 2016:62). Rumus untuk mencari Inventory turnover dapat digunakan sebagai berikut:

Receivable twrnover $=\frac{\text { penjualan kredit }}{\text { piutang }}$

4. Inventory Turnover atau Perputaran Persediaan

Menurut Sugiono dan Untung (2016:62). Inventory Turn Over atau merupakan rasio yang menunjukan berapa kali persediaan dapat berputar dalam satu tahun. Semakin tinggi tingkat persediaan, maka semakin cepat dana yang tertanam dalam persediaan berputar kembali menjadi uang kas. Rumus untuk mencari Inventory turnover dapat digunakan sebagai berikut:

Inventory Twrnover $=\frac{\text { Penjualan }}{\text { Persediagn }}$

5. Working Capital Turnover atau Perputaran Modal

Kerja Ratio ini menunjukan hubungan antara modal kerja dengan penjualan dan menunjukan banyaknya penjualan yang dapat diperoleh perusahaan (jumlah Rupiah) untuk tiap Rupiah modal kerja. Munawir, (2014:73). Rumus yang digunakan untuk mencari perputaran modal kerja adalah sebagai berikut:

Perputaran Modal Kerja $=\frac{\text { Penjualan Bersit }}{\text { Modal Kerja }}$

Jadi dari ke lima rasio modal kerja yang telah dijelaskan, dalam penelitian ini hanya akan menggunakan Empat rasio yang sesuai dengan latar belakang yang ada yaitu:

1. Rasio Lancar (Current Ratio)

2. Perputaran Piutang (Receivable Turnover)

3. Perputaran Persediaan (Inventory Turnover)

4. Perputaran Modal Kerja (Working Capital Turnover)

\subsection{Rasio Profitabilitas}

Tujuan akhir yang ingin dicapai dari suatu perusahaan yang terpenting adalah memperoleh laba atau keuntungan yang maksimal, disamping hal-hal lainnya. Untuk mengukur tingkat keuntungan suatu perusahaan, digunakan rasio keuntungan atau rasio profitabilitas yang dikenal juga dengan rasio retabilitas. Kasmir, (2015196).

\subsubsection{Jenis-jenis Profitabilitas}

Menurut Sujarweni (2017) Rasio yang digunakan dalam mengukur tingkat profitabilitas adalah sebagai berikut:

a. Gross Profit Margin (Margin Laba Kotor)

Merupakan perbandingan antar penjualan bersih dikurangi dengan harga pokok penjualan dengan tingkat penjualan, rasio ini menggambarkan laba kotor yang dapat dicapai dari jumlah penjualan. Rasio ini dapat dihitung dengan rumus yaitu:

Gross Profit Margin $=\frac{\text { Laba Kotor }}{\text { Penjualan Bersih }}$

b. Net Profit Margin (Margin Laba Bersih)

Merupakan rasio yang digunakan untuk mengukur laba bersih sesudah pajak lalu dibandingkan dengan volume penjualan. Rasio ini dapat dihitung dengan rumus yaitu:

Net Profit Margin $=\frac{\text { Laba Setelah Pajak }}{\text { Penjualan Bersih }}$

\section{c. Earning Power Of Total Invesment}

(Rate Of Return On Total Assets/ROA)

Merupakan rasio yang digunakan untuk mengukur kemampuan dari modal yang diinvestasikan dalam keseluruhan aktiva untuk menghasilkan keuntungan netto. Rasio ini dapat dihitung dengan rumus yaitu: 
Earning Power of Total Invesment = Laba sebelum Bunga dan Pajak

Total Aktiva

\section{d. Rate of Return For the Owners (Rate of Return On Net Worth)}

Merupakan rasio yang digunakan untuk mengukur kemampuan dari modal sendiri untuk menghasilkan keuntungan bagi seluruh pemegang saham, baik saham biasa maupun saham preferen. Rasio ini dapat dihitung dengan rumus yaitu :

Return on Equity =

\section{Laba Bersih Setelah Pajak}

\section{Modal Sendiri}

\section{e. Operating Income Ratio / Operating Profit Margin}

Laba bersih sebelum bunga dan pajak yang dihasilkan oleh setiap rupiah penjualan. Rasio ini dapat dihitung dengan rumus yaitu:

\section{Operating Income Ratio =}

$\underline{\text { Penjualan Netto }}=\underline{\text { HPP }}=\underline{\text { Biaya Adm. }}$ Penjualan, Umum

$$
\text { Penjualan Netto }
$$

\section{f. Operating Ratio}

Biaya operasi per rupiah penjualan. Rasio ini dapat dihitung dengan rumus yaitu:

\section{Net on Equity = \\ HPP + Biaya Adm.Penjualan, Umum \\ Penjualan Umum}

Beberapa perhitungan rasio profitabilitas tersebut, analisis rasio profitabilitas dalam penelitian ini diukur menggunakan rasio profitabilitas yang berkaitan dengan investasi/aset (ROA), karena (ROA) merupakan pengukuran kemampuan perusahaan secara keseluruhan didalam menghasilkan keuntungan dengan jumlah keseluruhan aktiva yang tersedia di dalam perusahaan, semakin tinggi ratio ini semakin baik keadaan suatu perusahaan.
Munawir menyatakan bahwa Return on Assets (ROA/ROI) adalah salah satu bentuk dari ratio profitabilitas yang dimaksudkan untuk dapat mengukur kemampuan perusahaan dengan keseluruhan dana yang ditanamkan dalam aktiva yang digunakan untuk operasinya perusahaan untuk menghasilkan keuntungan.

\section{METODE PENELITIAN}

\subsection{Jenis Penelitian}

Jenis data yang digunakan dalam penelitian ini adalah kuantitatif kausalitas. Dalam penelitian ini menggunakan variabel Rasio Lancar (X1), Perputaran Piutang (X2), Perputaran Persediaan (X3), Perputaran Modal Kerja (X4) merupakan sebagai variabel bebas (independen) dan Profitabilitas (Y) merupakan sebagai variabel terikat (dependen).

\subsection{Lokasi dan Waktu Penelitian}

Penelitian ini dilakukan secara desk study yaitu penelitian yang dilakukan dimeja tugas dimana data-data dikumpulkan kemudian diolah dengan menggunakan data-data laporan keuangan perusahaan yang terdapat di website resmi BEI yaitu di www.idx.co.id. Penelitian ini dilakukan pada bulan Juli 2018 - Juli 2019.

\subsection{Objek Penelitian}

Objek dari penelitian ini adalah laporan posisi keuangan konsolidasi, laporan laba-rugi komperhensif pada perusahaan makanan dan minuman yang terdaftar di Bursa Efek Indonesia.

\subsection{Populasi dan Sampel}

Dalam penelitian ini yang dijadikan populasi adalah perusahaan-perusahaan makanan dan minuman yang terdaftar di Bursa Efek Indonesia.

Sampel yang digunakan adalah 7 Perusahaan makanan dan minuman yang terdaftar di BEI yaitu : PT Mayora Indah 
Tbk, PT Akasha Wira Internasional Tbk, PT Nippon Indosari Corporindo Tbk, PT Indofood CBP Sukses Makmur Tbk, PT Tiga Pilar Sejahtera Food Tbk, PT Sekar Bumi Tbk, PT Siantar Top Tbk.

\subsection{Metode Analisa}

Pada metode analisa data yang digunakan dalam memecahkan masalah berupa uji asumsi klasik, uji analisis regresi linear berganda, dan uji hipotesis, Uji Koefisien Determinasi.

\section{HASIL DAN PEMBAHASAN}

\subsection{Input Data 7 Sampel Perusahaan}

Tabel 2. Hasil Input Data 7 Sampel Perusahaan

\begin{tabular}{|c|c|c|c|c|c|c|}
\hline & & $\mathrm{xl}$ & $\mathrm{x} 2$ & $\mathrm{x} 3$ & $\mathrm{x} 4$ & $\mathrm{Y}$ \\
\hline Perusabaan & Tahuu & $\begin{array}{c}\text { Rasio } \\
\text { Laucar }\end{array}$ & $\begin{array}{l}\text { Perputaran } \\
\text { Piutang }\end{array}$ & $\begin{array}{l}\text { Perputaran } \\
\text { Persediaan }\end{array}$ & $\begin{array}{l}\text { Perputaran } \\
\text { Modal Kerja }\end{array}$ & $\mathrm{ROA}$ \\
\hline \multirow{5}{*}{ MAYORA } & 2013 & 244 & 430 & 8.25 & 0.36 & 10.90 \\
\hline & 2014 & 207 & 4.65 & 720 & 421 & 3.98 \\
\hline & 2015 & 237 & 4.40 & 8.45 & 3.44 & 11.02 \\
\hline & 2016 & 225 & 420 & 8.64 & 3.78 & 10.36 \\
\hline & 2017 & 239 & 3.62 & 11.40 & 3.36 & 10.93 \\
\hline \multirow{5}{*}{ AKASHA } & 2013 & 1.81 & 6.36 & 5.93 & 5.71 & 12.62 \\
\hline & 2014 & 1.54 & 5.57 & 6.26 & 6.89 & 6.14 \\
\hline & 2015 & 1.39 & 5.34 & 6.75 & 8.70 & 5.03 \\
\hline & 2016 & 1.64 & 5.82 & 9.30 & 7.15 & 7.29 \\
\hline & 2017 & 1.20 & 5.79 & 754 & 16.50 & 455 \\
\hline \multirow{5}{*}{ NIPPON } & 2013 & 1.14 & 8.24 & 41.22 & 34.46 & 8.67 \\
\hline & 2014 & 1.37 & 8.81 & 46.09 & 16.68 & 8.80 \\
\hline & 2015 & 205 & 8.74 & 50.37 & 5.21 & 10.00 \\
\hline & 2016 & 296 & 8.99 & 49.70 & 4.01 & 9.58 \\
\hline & 2017 & 226 & 7.67 & 49.56 & 193 & 297 \\
\hline \multirow{5}{*}{ INDOFOOD } & 2013 & 241 & 10.22 & 8.75 & 3.79 & 10.51 \\
\hline & 2014 & 218 & 11.14 & 10.64 & 4.07 & 10.16 \\
\hline & 2015 & 2.33 & 9.93 & 1245 & 3.99 & 11.01 \\
\hline & 2016 & 241 & 9.26 & 11.08 & 3.79 & 1256 \\
\hline & 2017 & 243 & 9.20 & 10.92 & 3.65 & 11.21 \\
\hline \multirow{5}{*}{$\begin{array}{l}\text { TIGA } \\
\text { PILAR }\end{array}$} & 2013 & 1.75 & 4.48 & 3.96 & 3.87 & 691 \\
\hline & 2014 & 266 & 3.82 & 4.14 & 2.07 & 450 \\
\hline & 2015 & 1.62 & 3.04 & 3.83 & 3.51 & 4.12 \\
\hline & 2016 & 2.38 & 2.73 & 3.16 & 1.90 & 7.64 \\
\hline & 2017 & 1.16 & 233 & 3.51 & 7.76 & 9.85 \\
\hline \multirow{5}{*}{$\begin{array}{l}\text { SEKAR } \\
\text { BUMI }\end{array}$} & 2013 & 1.25 & 9.38 & 1458 & 19.26 & 11.71 \\
\hline & 2014 & 1.48 & 13.57 & 13.25 & 1.21 & 13.72 \\
\hline & 2015 & 1.15 & 14.45 & 1254 & 31.46 & 5.25 \\
\hline & 2016 & 1.11 & 9.49 & 6.30 & 29.85 & 2.25 \\
\hline & 2017 & 1.64 & 9.18 & 6.28 & 5.67 & 1.59 \\
\hline \multirow{5}{*}{$\underset{\text { TOP }}{\text { SIANTAR }}$} & 2013 & 1.14 & 7.79 & 5.93 & 19.88 & 7.78 \\
\hline & 2014 & 1.48 & 836 & 7.01 & 8.32 & 7.26 \\
\hline & 2015 & 1.58 & 8.80 & 852 & 793 & 9.56 \\
\hline & 2016 & 1.65 & 7.28 & 9.39 & 7.22 & 731 \\
\hline & 2017 & 2.64 & 7.63 & 9.45 & 4.80 & 9.21 \\
\hline
\end{tabular}

Sumber: Data diolah, 2019

Dari diatas dapat kita ambil kesimpulan bahwa Retun On Assets dari ke tujuh sampel perusahaan makanan dan minuman yang terdaftar di BEI berfluktuasi dalam setiap laporan tahunan selama periode 2013 sampai dengan 2017.

Return On Assets (ROA) yang selalu berfluktuasi menjadi indikator bahwa perusahaan-perusahaan tersebut belum mampu menggunakan dananya secara efektif dan juga belum bisa memaksimalkan aktiva yang ada untuk mendapatkan keuntungan yang diharapkan.

\subsection{Uji Asumsi Klasik \\ 4.2.1 Uji Normalitas}

Uji normalitas bertujuan untuk menguji apakan nilai residual pada model regresi berdistribusi normal atau tidak.

Dasar pengambilan keputusan uji statistic dengan Kolmogorov-Sminov $(K-S)$ adalah:

1. Jika nilai sig (signifikansi) $>0,05$ maka terima $\mathrm{HO} \rightarrow$ data berdistribusi normal.

2. Jika nilai sig (signifikansi) $<0,05$ maka tolak $\mathrm{HO}->$ data berdistribusi normal.

Tabel 3. Hasil Uji Normalitas

One-Sample Kolmogorov-Smirnov Test

\begin{tabular}{|ll|r|}
\hline & & $\begin{array}{r}\text { Unstandardized } \\
\text { Residual }\end{array}$ \\
\hline Normal Parameters ${ }^{\mathrm{a}, \mathrm{b}}$ & Mean & 35 \\
& Std. &, 0000000 \\
& Deviatio & 3,59570982 \\
Most Extreme & $\mathrm{n}$ &, 172 \\
Differences & Absolute &, 097 \\
& Positive &,- 172 \\
Kolmogorov-Smirnov Z & Negative & 1,016 \\
Asymp. Sig. (2-tailed) & &, 253 \\
\hline
\end{tabular}

Sumber: Data diolah, 2019

Berdasarkan tabel diatas, diketahui bahwa nilai signifikansi sebesar 0,253 lebih besar dari 0,05 , sehingga dapat disimpulkan bahwa H0 diterima dan data berdistribusi normal.

\subsubsection{Uji Heterokedastisitas}

Uji Heterokedasitas untuk menguji apakah dalam model regresi terjadi ketidaksamaan variance dari residual satu pengamatan ke pengamatan yang lain. 
Dasar pengambilan keputusan berdasarkan jika nilai sig $>0,05$ maka tidak terjadi heterokedasitas. Dan jika nilai sig < 0,05 maka terjadi heterokedasitas.

Tabel 4. Hasil Uji Glejser

\begin{tabular}{|c|c|c|c|c|c|}
\hline & & Coeffici & ents $^{\mathrm{a}}$ & & \\
\hline \multirow{2}{*}{ Model } & \multicolumn{2}{|c|}{$\begin{array}{c}\text { Unstandardized } \\
\text { Coefficients }\end{array}$} & \multirow{2}{*}{\begin{tabular}{|c}
$\begin{array}{c}\text { Standardized } \\
\text { Coefficients }\end{array}$ \\
Beta
\end{tabular}} & \multirow{2}{*}{$\mathrm{t}$} & \multirow{2}{*}{ Sig. } \\
\hline & B & Std. Error & & & \\
\hline 1 (Constant) & 5,02 & 2,672 & & 1,879 & 070 \\
\hline Rasio & -931 & 1160 & -210 & -803 & 428 \\
\hline Lancar & 201 & & -210 & 003 & $=+20$ \\
\hline Perputaran & -143 & 158 & -177 & -.905 & 373 \\
\hline Piutang & & & & & \\
\hline Perputaran & 023 & 032 & 136 & 704 & 487 \\
\hline Persediaan &, 020 & & & & \\
\hline $\begin{array}{l}\text { Perputaran } \\
\text { Modal Kerja }\end{array}$ & 012 &, 074 & 044 &, 160 & 874 \\
\hline
\end{tabular}

Sumber: Data diolah, 2019

Jadi kesimpulan dari semua variabel independent (X) memperoleh sig lebih besar dari nilai 0,05 jadi dapat disimpulkan tidak terjadi heterokedasitas.

\subsubsection{Uji Multikolinearitas}

Uji multikolinearitas untuk menguji apakah dalam model regresi ditemukan adanya kolerasi antara variabel bebas. Model regresi yang baik seharusnya tidak terjadi terjadi korelasi variabel bebas.

Dasar pengambilan keputusan:

1. Tolerance > 0,05 tidak terjadi multikolinearitas.

2. Tolerance < 0,05 terjadi multikolinearitas.

Berdasarkan nilai VIF:

1. VIF $<10,00$ tidak terjadi multikolinearitas

2. VIF $>10,00$ terjadi multikolinearitas.
Tabel 5. Hasil Uji Multikolinearitas

Coefficients $^{\mathbf{a}}$

\begin{tabular}{|ll|r|c|}
\hline \multirow{2}{*}{ Model } & \multicolumn{2}{|c|}{ Collinearity Statistics } \\
\cline { 2 - 3 } & Tolerance & \multicolumn{1}{c|}{ VIF } \\
\hline 1 Rasio Lancar &, 450 & 2,220 \\
& Perputaran Piutang &, 809 & 1,236 \\
$\quad$ Perputaran &, 822 & 1,216 \\
$\quad$ Persediaan & & \\
$\quad$ Perputaran Modal &, 415 & 2,408 \\
$\quad$ Kerja & & \\
\hline
\end{tabular}

Sumber: Data diolah, 2019

Keempat variabel bebas X1 (Rasio lancar), X2 (Perputaran Piutang), X3 (Perputaran Persediaan), X4 (Perputaran Modal Kerja) tidak terjadi multikolinearitas karena nilai tolerance (>) lebih besar dari 0,05 dan nilai VIF lebih kecil $(<)$ dari 10,00 .

\subsubsection{Uji Autokorelasi}

\begin{tabular}{|c|r|r|r|r|r|}
\hline Model & Model Summary & \\
\hline & $R$ & R Square & $\begin{array}{c}\text { Adjusted R } \\
\text { Square }\end{array}$ & $\begin{array}{c}\text { Std. Error } \\
\text { of the } \\
\text { Estimate }\end{array}$ & $\begin{array}{c}\text { Durbin- } \\
\text { Watson }\end{array}$ \\
\hline & $.406^{2}$ & .165 & .053 & 308.486 & 1.445 \\
\hline
\end{tabular}

a. Predictors: (Constant), perputaran modal kerja, perputaran persediaan, perputaran piutang, Rasio lancar

b. Dependent Variable: ROA

Sumber: Data diolah, 2019

Hasil uji autokorelasi bertujuan untuk menguji apakah dalam sebuah model regresi linear ada korelasi antara kesalahan penggangu (eror) pada periode dengan kesalahan penggangu pada periode sebelumnya, jika ada berarti terdapat autokorelasi.

Pada pengujian autokorelasi digunakan uji Durbin-Watson untuk mengetahui ada tidaknya autokorelasi pada model regresi dan berikut ini nilai Durbin-Watson yang diperoleh melalui hasil estimasi model regresi.

Tabel 6. Nilai Uji DW

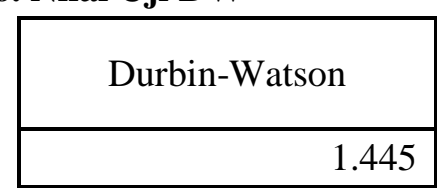

Sumber: Data diolah, 2019 
Berdasarkan tabel diatas hasil pengelolaan diperoleh nilai statistik Durbin-Watson $(\mathrm{D}-\mathrm{W})=1,445$, sementara dari tabel Durbin-Watson pada tingkat kekeliruan 5\% untuk jumlah variabel bebas $(\mathrm{k})=4$ dan jumlah pengamatan $\mathrm{n}=35$ diperoleh batas bawah nilai tabel $(\mathrm{dL})=$ 1,2221 dan batas atasnya $(\mathrm{dU})=1,7259$. Nilai Durbin-Watson model regresi $(1,445)$ berada diantara $\mathrm{dL}=1,2221 \leq \mathrm{DW}(1,445)$ $\leq \mathrm{dU}=1,7259$, yaitu didaerah tidak ada keputusan maka belum dapat disimpulkan apakah terjadi autokorelasi pada model regresi.

Untuk memastikan ada tidaknya autokorelasi maka pengujian dilakukan menggunakan Runs Test.

Runs test merupakan salah satu analisis non-parametik yang dapat digunakan untuk menguji residual terdapat korelasi yang tinggi. Jika antar residual tidak terdapat korelasi maka dikatakan bahwa nilai residual adalah acak atau random. Runs test digunakan untuk melihat apakah data residual terjadi secara random atau tidak (sistematis).

Tabel 7. Hasil Uji Runs Test

\begin{tabular}{|l|r|}
\hline \multicolumn{2}{|c|}{ Runs Test } \\
\hline & $\begin{array}{c}\text { Unstandardized } \\
\text { Residual }\end{array}$ \\
\hline Test Value $^{\mathrm{a}}$ &, 42374 \\
Cases < Test Value & 17 \\
Cases > = Test Value & 18 \\
Total Cases & 35 \\
Number of Runs & 20 \\
Z &, 348 \\
Asymp. Sig. (2-tailed) &, 728 \\
\hline
\end{tabular}

Sumber: Data diolah, 2019

Pada output runs test diatas terlihat bahwa nilai test 0,42374 sedangkan nilai probabilitasnya adalah 0,728 . Untuk menyimpulkan apakah terjadi gejala autokorelasi atau tidak maka nilai test dibandingkan dengan nilai tabel atau nilai probabilitas dibandingkan dengan dengan nilai alphanya.

Berdasarkan output tersebut diperoleh nilai probabilitas sebesar 0,728 lebih besar dari pada 0,05. Dengan demikian dapat disimpulkan tidak terjadi autokorelasi.

\subsection{Uji Regresi Linier Berganda}

Analisis regresi berganda bertujuan untuk mengetahui ada atau tidaknya pengaruh dua atau lebih variabel bebas (X) terhadap variabel $(\mathrm{Y})$.

\section{Tabel 8. Hasil Uji Regresi Linier Berganda}

\begin{tabular}{|c|c|c|c|c|c|}
\hline & & Coeffic & ients ${ }^{a}$ & & \\
\hline \multirow[t]{2}{*}{ Model } & \multicolumn{2}{|c|}{$\begin{array}{c}\text { Unstandardized } \\
\text { Coefficients }\end{array}$} & \multirow{2}{*}{\begin{tabular}{|c|}
$\begin{array}{c}\text { Standardized } \\
\text { Coefficients }\end{array}$ \\
Beta
\end{tabular}} & \multirow[t]{2}{*}{$t$} & \multirow[t]{2}{*}{ Sig. } \\
\hline & $B$ & Std. Error & & & \\
\hline 1 (Constant) & $-4,063$ & 4,195 & &., 969 &, 341 \\
\hline Rasio & 3819 & 1.821 & .468 & 2.097 & .045 \\
\hline Lancar & & & & & \\
\hline Perputaran & .651 & .247 & .438 & 2.634 & .013 \\
\hline $\begin{array}{l}\text { Piutang } \\
\text { Perputaran }\end{array}$ & & & & & \\
\hline Persediaan & -013 &, 051 & -,041 & -250 &, 804 \\
\hline Perputaran & & & & & \\
\hline Modal &, 001 &, 117 &, 002 &, 011 &, 992 \\
\hline Kerja & & & & & \\
\hline
\end{tabular}

Sumber: Data diolah, 2019

Model persamaan regresi yang dapat dituliskan dari hasil analisis diatas adalah dalam bentuk persamaan regresi adalah sebagai berikut:

$\mathrm{Y}=-4,063+3,819 \mathrm{X} 1+0,651 \mathrm{X} 2-0,013$

$\mathrm{X} 3+0,001 \mathrm{X} 4$

Persamaan regresi diatas dapat dijelaskan sebagai berikut:

1. Konstanta, jika tidak ada rasio lancar, perputaran piutang, perputaran persediaan, dan perputaran modal kerja maka profitabilitas (Return On Assets) tetap konstan sebesar $-4,063$.

2. Variabel rasio lancar $=3,819$, artinya jika ada peningkatan 1 satuan rasio lancar maka profitabilitas (Return On Assets) akan meningkat sebesar 3,819 satuan.

3. Variabel perputaran piutang $=0,651$, artinya jika ada peningkatan 1 satuan perputaran piutang maka profitabilitas 
(Return On Assets) akan meningkat sebesar 0,651 satuan.

4. Variabel perputaran persediaan = 0,013 artinya jika ada peningkatan 1 satuan perputaran persediaan maka profitabilitas (Return On Assets) akan menurun sebesar 0,013 satuan.

5. Variabel perputaran modal kerja $=$ 0,001 , artinya jika ada peningkatan 1 satuan perputaran modal kerja maka profitabilitas (Return On Assets) akan meningkat sebesar 0,001 satuan.

\subsection{Uji Hipotesis}

\subsubsection{Uji Parsial (Uji t)}

Uji t bertujuan untuk mengetahui ada atau tidaknya pengaruh parsial (sendiri) yang diberikan variabel bebas (X) terhadap variabel terikat (Y).

\section{Tabel 9. Hasil Uji Parsial (Uji t)}

\begin{tabular}{|c|c|c|c|c|c|c|}
\hline \multicolumn{7}{|c|}{ Coefficients $^{\mathrm{a}}$} \\
\hline \multirow{2}{*}{\multicolumn{2}{|c|}{ Model }} & \multicolumn{2}{|c|}{$\begin{array}{l}\text { Unstandardized } \\
\text { Coefficients }\end{array}$} & \multirow{2}{*}{\begin{tabular}{c|}
$\begin{array}{c}\text { Standardized } \\
\text { Coefficients }\end{array}$ \\
Beta
\end{tabular}} & \multirow[t]{2}{*}{ t } & \multirow[t]{2}{*}{ Sig. } \\
\hline & & B & Std. Error & & & \\
\hline \multirow[t]{8}{*}{1} & (Constant) & $-4,063$ & 4,195 & & -969 &, 341 \\
\hline & Rasio & & & 468 & 2007 & 045 \\
\hline & Lancar & 3,819 & 1,821 & & & \\
\hline & $\begin{array}{l}\text { Perputaran } \\
\text { Piutang }\end{array}$ & ,651 & ,247 & ,438 & 2,634 &, 013 \\
\hline & Perputaran & 0013 & 051 & 041 & 950 & 804 \\
\hline & Persediaan &,- 015 & | & $-, 041]$ &,- 250 & 804 \\
\hline & Perputaran & & & & & \\
\hline & $\begin{array}{l}\text { Modal } \\
\text { Kerja }\end{array}$ &, 001 &, 117 &, 002 & 011 &, 992 \\
\hline
\end{tabular}

a. Dependent Variable: ROA

Sumber: Data diolah, 2019

Dasar pengambilan keputusan:

1. Jika nilai sig $\leq 0,05$, atau $t$ hitung $\geq \mathrm{t}$ tabel maka terdapat pengaruh variabel $\mathrm{X}$ terhadap variabel $\mathrm{Y}$.

2. Jika nilai sig $\geq 0,05$, atau t hitung $\leq \mathrm{t}$ tabel maka tidak terdapat pengaruh variabel $\mathrm{X}$ dan $\mathrm{Y}$.

$\mathrm{t}$ tabel $=\mathrm{t}(\mathrm{a} / 2 ; \mathrm{n}-\mathrm{k}-1)=(0,025 ; 30)=$ 2,042

Kesimpulan :

1. Pengujian hipotesis pertama (H1), Diketahui nilai sig untuk pengaruh $\mathrm{X} 1$ terhadap Y sebesar 0,045 $<0,05$ dan nilai t hitung 2,097 > 2,042, sehingga dapat disimpulkan $\mathrm{H} 1$ diterima yang berarti terdapat pengaruh antara $\mathrm{X} 1$ (Rasio lancar) terhadap Y (ROA).

2. Pengujian hipotesis kedua (H2), Diketahui nilai sig untuk pengaruh $\mathrm{X} 2$ terhadap Y sebesar 0,013 $<0,05$ dan nilai t hitung 2,634>2,042, sehingga dapat disimpulkan $\mathrm{H} 2$ diterima yang berarti terdapat pengaruh antara $\mathrm{X} 2$ (Perputaran piutang) terhadap $\mathrm{Y}$ (ROA).

3. Pengujian hipotesis ketiga (H3), Diketahui nilai sig untuk pengaruh X3 terhadap Y sebesar 0,804 $>0,05$ dan nilai $t$ hitung $-0,250<2,042$, sehingga dapat disimpulkan $\mathrm{H} 3$ ditolak yang berarti tidak terdapat pengaruh antara X3 (Perputaran persediaan) terhadap Y (ROA).

4. Pengujian hipotesis keempat (H4), Diketahui nilai sig untuk pengaruh $\mathrm{X} 4$ terhadap Y sebesar 0,992 > 0,05 dan nilai t hitung $0,011<2,042$, sehingga dapat disimpulkan $\mathrm{H} 4$ ditolak yang berarti tidak dapat pengaruh antara $\mathrm{X} 4$ (Perputaran modal kerja) terhadap $\mathrm{Y}$ (ROA).

5. Untuk mengetahui nilai variabel bebas (X) yang paling dominan berpengaruh terhadap variabel terikat $(\mathrm{Y})$ digunakan Uji Standardized Coefficients Beta. Pengaruh dominan variabel bebas (X) terhadap variabel terikat (Y) diuji dengan menggunakan Standardized Coefficients Beta tertinggi. Dengan melihat hasil Standardized Coefficients Beta dari masing-masing variabel bebas diatas, yaitu yang meliputi Rasio lancar (X1), Perputaran piutang (X2), Perputaran persediaan (X3), dan Perputaran modal kerja (X4) pada tabel 4.11 maka dapat diketahui bahwa variabel bebas yang berpengaruh dominan terhadap variabel terikat ROA/Profitabilitas (Y) adalah variabel bebas Rasio Lancar (X1) karena menunjukan nilai Standardized Coefficients Beta yang lebih besar dari 
variabel bebas lainnya yaitu sebesar 0,468 .

\subsubsection{Uji Silmutan (Uji F)}

Uji $F$ digunakan untuk mengetahui apakah variabel independen secara bersama-sama berpengaruh signifikan terhadap variabel dependen.

Tabel 10. Hasil Uji Silmutan (Uji F)

\begin{tabular}{|rl|r|r|r|r|r|}
\hline \multicolumn{1}{|c|}{ Model } & $\begin{array}{r}\text { Sum of } \\
\text { Squares }\end{array}$ & Df & $\begin{array}{c}\text { Mean } \\
\text { Square }\end{array}$ & F & Sig. \\
\hline 1 & Regression & 214,01 & 4 & 53,503 & 3,651 &, $015^{\text {b }}$ \\
& Residual & 439,59 & 30 & 14,653 & & \\
Total & 653,601 & 34 & & & \\
\hline
\end{tabular}

a. Dependent Variable: ROA

b. Predictors: (Constant), Perputaran Modal Kerja, Perputaran Persediaan, Perputaran Piutang, Rasio Lancar.

Sumber: Data diolah, 2019

Dasar pengambilan keputusan:

1. Jika nilai Sig $\leq 0,05$, atau $F$ hitung $\geq F$ tabel maka terdapat pengaruh variabel $\mathrm{X}$ dan terhadap variabel Y.

2. Jika nilai $\operatorname{Sig} \geq 0,05$, atau $\mathrm{F}_{\text {hitung }} \leq \mathrm{F}$ tabel maka tidak terdapat pengaruh variabel $\mathrm{X}$ terhadap variabel $\mathrm{Y}$.

Berdasarkan hasil output SPSS maka dapat disimpulkan dimana nilai $F$ hitung lebih besar dari pada nilai $\mathrm{F}$ tabel ( 3,651 > 2,69 ) dengan tingkat signifikan dibawah 0,05 yaitu 0,015. Berdasarkan cara pengambilan keputusan uji simultan dalam analisis regresi dapat disimpulkan bahwa variabel Rasio Lancar (X1), Perputaran Piutang (X2), Perputaran Persediaam (X3), Perputaran Modal Kerja (X4) jika diuji bersama-sama atau serempak berpengaruh signifikan terhadap tingkat Profitabilitas (ROA).

\subsection{Uji Koefisien Determinasi $\left(\mathbf{R}^{2}\right)$}

Uji koefisien determinasi digunakan untuk mengukur seberapa besar kontribusi variabel bebas terhadap variabel terikat.
Tabel 11. Hasil Uji Koefisien Detrminasi $\left(\mathbf{R}^{2}\right)$

\begin{tabular}{|l|r|r|r|c|}
\multicolumn{7}{c}{ Model Summary } \\
\hline Model & \multicolumn{1}{c|}{$\mathrm{R}$} & $\begin{array}{c}\mathrm{R} \\
\text { Square }\end{array}$ & $\begin{array}{c}\text { Adjusted R } \\
\text { Square }\end{array}$ & $\begin{array}{c}\text { Std. Error of } \\
\text { the Estimate }\end{array}$ \\
\hline 1 &, $572^{\mathrm{a}}$ &, 327 &, 238 & 3,82793 \\
\hline
\end{tabular}

a. Predictors: (Constant), Perputaran Modal Kerja, Perputaran Persediaan, Perputaran Piutang, Rasio Lancar

Sumber: Data diolah, 2019

Berdasarkan output diatas diketahui nilai $R$ Square sebesar 0,327. Hal ini mengandung arti bahwa pengaruh variabel Rasio lancar, Perputaran piutang,

Perputaran persediaan dan Perputaran modal kerja secara simultan terhadap variabel $\mathrm{Y}$ (ROA) sebesar 32,7\% sedangkan sisanya $67,3 \%$ dijelaskan oleh sebab lain diluar model variabel.

\section{KESIMPULAN DAN SARAN}

\subsection{Kesimpulan}

Berdasarkan hasil maka kesimpulan dalam penelitian ini adalah sebagai berikut:

1. Variabel Rasio lancar berpengaruh positif terhadap tingkat profitabilitas (ROA) dengan nilai sig sebesar 0.045 $<0,05$ dan nilai t hitung 2,097 > 2,042.

2. Variabel Perputaran piutang berpengaruh positif terhadap tingkat profitabilitas (ROA) dengan nilai sig sebesar $0.013<0,05$ dan nilai $t$ hitung 2,634> 2,042.

3. Variabel Perputaran persediaan tidak berpengaruh terhadap tingkat profitabiilitas (ROA) dengan nilai sig sebesar 0,804 $>0,05$ dan nilai t hitung $-0,250<2,042$.

4. Variabel Perputaran modal kerja tidak berpengaruh terhadap tingkat profitabilitas (ROA) dengan nilai sig sebesar 0,992>0,05 dan nilai $t$ hitung $0,011<2,042$.

5. Variabel independen (Rasio Lancar, Perputaran Piutang, Perputaran Persediaan, Perputaran Modal Kerja) secara simultan berpengaruh terhadap Tingkat Profitabilitas (ROA) pada perusahaan makan dan minuman yang terdaftar di BEI periode 2013-2017. Ini 
dibuktikan dengan dimana nilai $\mathrm{F}$ hitung lebih besar dari pada nilai $\mathrm{F}$ tabel $(3,651>2,69)$ dengan tingkat signifikan dibawah 0,05 yaitu 0,015 .

6. Variabel yang memiliki pengaruh paling dominan terhadap tingkat profitabilitas (ROA) adalah variabel Rasio Lancar dengan nilai Standardized Coefficients Beta yang lebih besar dari variabel bebas lainnya yaitu sebesar 0,468.

7. Perusahaan yang paling baik dalam pengelolaan modal kerja adalah PT Indofood CBP Sukses Makmur Tbk. Dapat dilihat dari estimasi rata-rata rasio Profitabilitas (ROA) tertinggi sebesar $11 \%$ dengan tingkat Rasio Lancar tertinggi sebesar 2,35 kali. Hal ini sesuai dengan hasil dari penelitian ini, dimana Rasio Lancar paling dominan berpengaruh terhadap tingkat Profitabilitas (ROA).

\subsection{Saran}

Berdasarkan hasil berikut saran:

1. Sebaiknya PT Akasaha Wira Internasional, PT Nippon Indosari Corporindo Tbk, PT Tiga Pilar Sejahtara Tbk, PT Sekar Bumi Tbk dan PT Siantar TOP Tbk dapat mengatur dan mengelola perputaran Rasio Lancar untuk eningkatkan operasional perusahaan dalam memaksimalkan profitabilitas perusahaan.

2. Perusahaan diharapkan dapat mengatur perputaran piutang agar dapat berputar secara cepat dalam satu periode.

3. Diharapkan ada penelitian lebih lanjut terhadap beberapa variabel lain yang dapat mempengaruhi profitabilitas.

4. Menggunakan jenis perusahaan yang berbeda dan memperpanjang periode penelitian.

\section{DAFTAR PUSTAKA}

\footnotetext{
Bursa Efek Indonesia. 2019. https://idx.co.id. [12 April 2019].
}

Desi Puspitasari. 2017. Pengaruh Perputaran Modal Kerja Terhadap Profitabilitas PT Akasha Wira Internasional Tbk. Jurnal. Sekolah Tinggi Ilmu Ekonomi Widya Darma Pontianak.

Edu saham. 2019. Edusaham.com/2019/04/perusahaansektor-industri-barang-konsumsi-yangterdaftar-di-bei.html [12 Agustus 2019].

Fahmi, Irham. 2012. Pengantar Manajemen Keuangan. Alfabeta. Bandung. 2012. Analisis Kinerja Keuangan. Alfabeta. Bandung.

Fitroh Setianingsih. 2018. Analisis Pengaruh Pengelolaan Modal Kerja Terhadap Tingkat Profitabilitas (ROA). Skripsi. STIE Dewantara.

Hery. 2015. Pengantar Akuntansi. Gramedia Widiasarana. Jakarta. ------. 2017. Teori Akuntansi Pendekatan Konsep dan Analisis. Gramedia Widiasarana. Jakarta.

PT Raya Grafindo Persada. Jakarta.

Jurnal Nasinal. 2016. Industri Makanan Optimis Tumbuh. www.kemenperin.go.id/artikel/4673/In dustri-Makanan-Optimis-Tumbuh. [15 Maret 2019].

Mardiyanto, Handoyo. 2017. SPSS 24 Untuk Penelitian Dan Skripsi. PT Alex Media Komputindo. Jakarta.

Mohamad Aryo Arifin. 2018. Pengelolaan Modal Kerja Terhadap Profitabilitas Perusahaan Food dan Beverage. Jurnal. Universitas PGRI Palembang.

Munawir, S. 2014. Analisis Laporan Keuangan. Liberty. Yogyakarta.

Rina Angreani. 2019. Industri Makanan dan Minuman Jadi Andalan. 